\title{
消化器癌患者の細胞性免疫に関する研究
}

\author{
リンパ球幼若化反応を中心として \\ 京都府立医科大学第 2 外科学教室（指導：檑本 勇教授） \\ 松本学
}

\section{STUDIES CONCERNING CELL MEDIATED IMMUNITY IN DIGESTIVE CANCER PATIENTS WITH LYMPHOCYTE BLASTOID TRANSFORMATION}

\section{Manabu MATSUMOTO}

2 nd Department of Surgery, Kyoto Prefectural University of Medicine

(Director : Prof. Isamu HASHIMOTO)

消化器癌患者237例を対象にして, 細胞性免疫能を全身的なものと, 癌病巣に 所属するリンパ節細胞の 兔疫応答とに区別し, in vitro のリンバ球幼若化反応を指標にして検討した.

1） PHA 幼若化反応を指標にした全身的な免疫能は, 癌患者 (S.I. = 52.9 23.4) では健康人 $(n=92$, S.I. $=103.7 \pm 34.4)$ 飞比し有意な低下を認め $(\mathrm{p}<0.01)$ ，また癌が進行するに従って低下傾向が認めら れた．胃癌患者で領域りン八節の採取できた18例につき局所の免疫能を検討すると；全身的な免疫反応に 比べて増強傾向が認められた。

2）非特異的免疫賦活剤を投与された 5 例につき特異免疫能（MLTR）の变動を検討すると 3 例（60 \%) に改善傾向が認められた。

索引用語：細胞性免疫，リンパ球幼若化率，領域リンパ節細胞，癌免疫療法

\section{I 緒 言}

近年の免疫学の進歩により担癌生体の免疫能に関する 知見が多く認められている.生体にとって異物ともいう べき腫瘍が発生すると, 生体では主として胸腺依存性り ンパ球 (T-cell) がこれを排除しようと動らきここに 細胞性免疫が成立する. 動物の実験腫瘍では細胞性免疫 の解析がなされている(12)31，一方人癌に和いても，種々 の方法により免疫能の解析がなされている. 解析の方 法には感作リンパ球が産生するリンホカインを測定す る assay と，感作リンバ球の腫瘍細胞障害能を測定する assay があるが，前者に属するものにはマクロファージ 遊走阻止試験, 白血球遊走阻止試験, リン八球幼若化反 応などがあり，後者には細胞障害試験，コロニ一阻止試 験などがある.こ机らの測定法のらら，いずれを選択す るかについては，な怙多くの意見がありかならずしも一 定の見解は認められないが, 本研究では著者は主として
リンパ球幼若化反応を測定することによって担癌生体の 細胞性免疫能を解析する方法を選んだ.

1960年 Nowell によって Phytohaemagglutinin (以後 PHA と省略) が生体のリンパ球の芽球化を引き起こす 現象が報告(されれたが，1974年になって Greaves ら5゙は PHA がリンパ球のらち選択的に T-cell を芽球化させ ることを明らかてし報告した。しかしこの PHA による T-cell の mitogen は非特異的なるので腫瘍に関連する 特異的なものではない，そこで著者はリンパ球に PHA を添加して行う非特異的な T-cell の mitogen と以下に 述べる腫瘍特異的な検索を併せ行い生体の免疫能を解析 しようと試みた。

生体に存在する腫瘍特異抗原 (T.S.A) は, 最近の一 連の動物実験によりその存在が実証され報告されてはい るが ${ }^{6778899}$, 人癌に㔚ける腫瘍特異抗原の証明が困難な こともよく知られているところである. Stjernsward ら ${ }^{10}$ 
がリンパ球と自家の腫瘍細胞を混合培責し腫瘍特異抗 原の存在を示唆して以来, この方法による特異免疫能の 解析が行なわれるよらになった，著者む本研究では手 術時採取した尰漡細胞と, リンパ球との間で混合培䖯 (MLTR) を行い腫湟特異抗原の解析を行った.

一般に担癌生体では細胞性免疫能が低下していると考 えられているが，その原因として，体液性因子扰よび細 胞性因子の関与が考学られる. 体液性因子としては流血

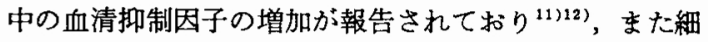
胞性因子としては suppressor cell の影響 ${ }^{13)}$ が考光られ， ，それぞれが全身的な免疫能に影響を与えると考えられ る. また近年癌病巣領域のリンパ節細胞には, 腫瘍増殖 を抑制する機構が存在すると考えられており、これは全 身的なものとは違って局所的危疫反応として理解されて いる. 著者はこの両者に関する検索を行らことを目的と して, 胃癌患者を対象に全身的な免疫能と, 領域リンパ 節での变化を指標とした局所的免疫能を比較検討した.

一方進行癌患者では，免疫能が著明に低下することが 知られているので, 最近では術前からその生体の免疫能 を改善することを目的にして非特異的免疫療法が施行さ れていることも多い.しかしこのような非特異的免疫療 法によって，はたして癌に対する特異免疫能の増強さ兄 も期待できるかどらかについては甚た疑問である，そこ で著者はこの問題を解析するため, 術前に行ら免疫療法 に先立って，まず末梢血リンパ球を採取し，これを凍結

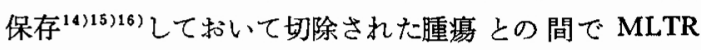
を行い,この結果を指標として特異免疫能の推移を検討 した. 同時に術前の免疫療法により局所の免疫能に与兄 る影響を胃癌患者の領域リンパ節リンパ球を指標に検討 した。

\section{II 対象および検索方法}

対象症例は胃癌161例，食道癌26例，大腸癌43例，膵 臓癌 7 例, 良性疾患64例, 健康人92例, 総数393例であ る.

1）末梢血りンパ球の分離

術前数回早朝にヘパリン加末梢静脈血約 $7 \sim 8 \mathrm{ml}$ 採血 し, Ficoll-Conray 400 の約 $3 \mathrm{ml}$ の上飞重層し, 1,550回 転で30分間遠心し，分離されたりンパ球層を10\% Fetal Calf Serum (F.C.S. Gibco 社) を含むRPMI-1,640 培 養液 (Gibco 社) に浮遊させ 2 回洗滌後, 細胞数を $1 \times$ $10^{6}$ 個 $/ \mathrm{ml}$ に調整した。

2）リンパ節リンパ球の分離

手術時無菌的にリンパ節を採取し, teflon mesh 上に
て眼科用鋏で細切濾過し，以下末梢血リンパ球分離と同 様の方法を用いてリンパ球を分離した。な採取したり ンパ節は半勿して, 一方はりンパ球分離に, 残り半分は 病理組織標本として転移の有無を検討した.

\section{3）腫場細胞の分離および調整}

原発主病巣または転移陽性と判明したリンパ節より 癌組織を採取し，ストレプトマイシン $200 \mu \mathrm{g} / \mathrm{ml}$ を含む 生理食塩水で充分洗滌後，眼科用錸で細切し， teflon mesh を用いて濾過し，0.25\%トリプシンを含むEagle's Minimun Essential Medium (Eagle's MEM) 培養液中 に浮遊させ， $37^{\circ} \mathrm{C} て ゙ 10$ 分間処理し，中和後 1,000 回転で 10分間遠心した. Eagle's MEM で2回洗涤後，20\% FCS 加 RPMI-1640 に 107個/ml になるように浮遊さ せ, 等量の Mitomycin C (MMC) $100 \mu \mathrm{g} / \mathrm{ml}$ を加え, $37^{\circ} \mathrm{C}$ で45分間作用させて癌細胞を不活性化しだ. その後 死細胞を除去するため, Ficoll-Conray 400 に重層し, 2,000回転で10分間遠心し, 中間層をとり浮遊させた. 分離後 trypan blue dye exclusion 法により生細胞を計 算し, 癌細胞浮遊液を $1 \times 10^{6} / \mathrm{ml}$ と $2 \times 10^{6} / \mathrm{ml}$ の 2 種 類作製した。

4）リンパ球の凍結保存

術前の免疫療法開始より 1 週間前に末梢血リンパ球 を採取し, 細胞数を $4 \times 10^{6} / \mathrm{ml}$ に調整し, 凍結保存用 バイアルに細胞凍害防止風である Dimethylsulfoxide (DMSO) を最終濃度が10\%になるように加え, 発泡ス チロール製の密封容器中ヘバイアルを入れ, アルコール 加ドライアイス中にて 2 時間緩徐凍結した. 次に液体窒 素中にて長期間保存した. 解凍は $42^{\circ} \mathrm{C}$ water bath 中に 3 分間入れ, DMSO の働らきを中和後, Eagle's MEM で 1 回洗滌し細胞数を $1 \times 10^{6} / \mathrm{ml}$ に調整した。

5）培養

i ) PHA 添加による培責

培養には micro test II tissue culture plate (Falcon Co. $\$ 3,040)$ を用い, 各 well 当りリンパ球浮遊液 $0.2 \mathrm{ml}$ (細胞数 $2 \times 10^{5}$ 個) を注入し, さらに repeating dispensor で PHA-P (Difco Co) が $0.02 \mathrm{ml}(15 \mu \mathrm{g} / \mathrm{ml}$ ) になるように加えた後 $5 \%$ 炭酸ガス培養器内で72時間培 養した. 培養終了 8 時間前に ${ }^{3} \mathrm{H}$-thymidine ( ${ }^{3} \mathrm{H}-\mathrm{TdR}$ ) を $0.02 \mathrm{ml}$ (最終濃度 $2 \mu \mathrm{ci} / \mathrm{ml}$ ) 加えた.

ii）リンパ球一尰湟混合培養

PHA 添加による培養と同様に微量測定法を用いて施 行した. 腫瘍細胞浮遊液は $0.02 \mathrm{ml}$ とし, 培屋は 5 日間 と 7 日間培盖の 2 群を作成し, 腫瘍細胞とリンパ球の比 
率は, $1 ： 5$ と1：10で検討した. 培養終了8時間前に ${ }^{3} \mathrm{H}-\mathrm{TdR}$ を $0.02 \mathrm{mI}$ 加忩た。

6）回収および放射活性

回収には Labo Mash Cell Harvestor (Labo Science Co）を使用し濾過回収後,フィルターを乾燥し, 液体シ ンチレーション用バイアルに入れ, シンチレーター夜を $10 \mathrm{ml}$ 加光, 液体シンチレーションカウンター (Packard Co., Tricarb 3,390) で放射活性を测定し, Stimulation Index (S.I.) は, 以下の式で算出した. 算出は Quadraplicate の median の平均值を用いた。

i ) PHA Kよるりンパ球幼若化率

$$
\text { S.I. }=-\frac{(\text { Vソバ球 }+ \text { PHA-P })^{\mathrm{dpm}}}{(\text { yンパ球のみ })^{\mathrm{dpm}}}
$$

ii）リンパ球一腫瘍混合培養に上る幼若化率

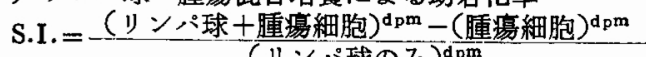
$\mathrm{dpm}^{*}=$ disintegrate per minute (リソパ球のみ $)^{\mathrm{d}} \mathrm{pm}$

\section{III 結 果}

(1) 全身的兔疫応答

i ) PHA 幼若化率

対象症例は消化器癌 237 例, 良性疾患64例, 健康人 92 例である. PHA 幼若化率は術前の未治療時のものを採 用した. 各疾患別の PHA 幼若化率 (S.I. = mean \pm S.D.) をみると, 癌患者では52.9 23.4 , 良性疾患（胃十二指

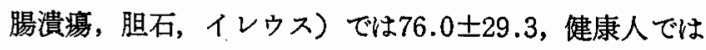
103.7士34.4であった. 癌患者を各臓器別にみると, 食 道癌50.7士28.9, 胃癌 $61.6 \pm 28.2$, 膵䐵癌 $39.9 \pm 19.6$, 大腸癌 $47.9 \pm 24.0$ であった. 癌患者では健康人に比し, 推計学的に PHA 幼若化率の有意の低下を認めた（表 1).

胃癌患者138例を胃癌取扱い規約 ${ }^{17}$ に従って進行度別 に分類すると, stage I 33例, stage II 25例， stage III 34 例, stage IV46例である. stage 別の PHA 幼若化率は, stage I $69.0 \pm 21.4$, stage II $64.1 \pm 19.2$, stage $\mathbb{I I} 62.4$ \pm 24.7 , stage IV46.2 \pm 20.5 であり, stage の進行にし たがって平均値の低下を認めた. stage I と stage IV, stage I と再発症例 $(n=23, \cdot$ S.I. $=28.1 \pm 11.6)$ では推 計学的に有意差を認め $(\mathrm{p}<0.01)$, stage $\mathrm{N}$, 再発症例 では stage I に比し有意の低下を認めた（図１）。

以上より癌患者では, 非特異的な細胞性免疫能の低下 が認められ，また癌の進行にともなって有意な低下を認 めた.

ii）リンパ球一腫瘍混合培養反応 (MLTR)

対象症例は食道癌 4 例, 胃癌35例, 大腸癌 5 例の計 44
表 1 PHA induced in vitro blastoid transformation in various malignant diseases

\begin{tabular}{|l|r|c|}
\hline primary case & $\mathbf{n}$ & $\begin{array}{c}\text { PHA Blastogenesis } \\
\text { mean } \pm \text { S.D. (S.I.) }\end{array}$ \\
\hline gastric ca. & 138 & $61.6 \pm 28.2$ \\
\hline $\begin{array}{l}\text { esophagus. ca. } \\
\text { colonic ca. }\end{array}$ & 26 & $50.7 \pm 28.2$ \\
\hline pancreatic ca. & 7 & $47.9 \pm 24.0$ \\
\hline \begin{tabular}{l} 
total \\
\hline benign \\
disease
\end{tabular} & 214 & $52.9 \pm 23.4$ \\
\hline \begin{tabular}{l} 
healthy \\
\hline
\end{tabular} & 92 & $103.7 \pm 34.4$ \\
\hline
\end{tabular}

malignant : healthy

disease : control $\quad \mathrm{p}<0.01$

図 1 PHA induced blastoid transformation in each stage of gastric cancer

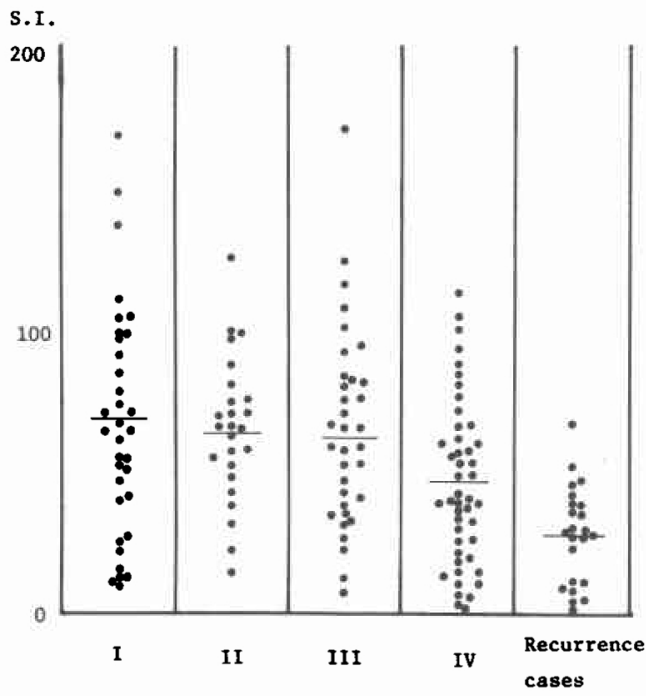

例である.

1) 腫㵣細胞の生細胞率の向上

手術時いかに多くの生細胞を採取できるかが問題とな るが，手術時の病巣摘出から腫場細胞採取まで時間が かかると死細胞が多くなる. そこで Ficoll-Conray を使 用し, 比重遠沈法を用いて死細胞の除去を試みた. 結果 は図 2 のごとく腫瘍細胞採取時 $10 \%$ 生細胞率が分離後 平均 $47 \%$ に上昇を認めた。 
図 2 Viability of tumor cells

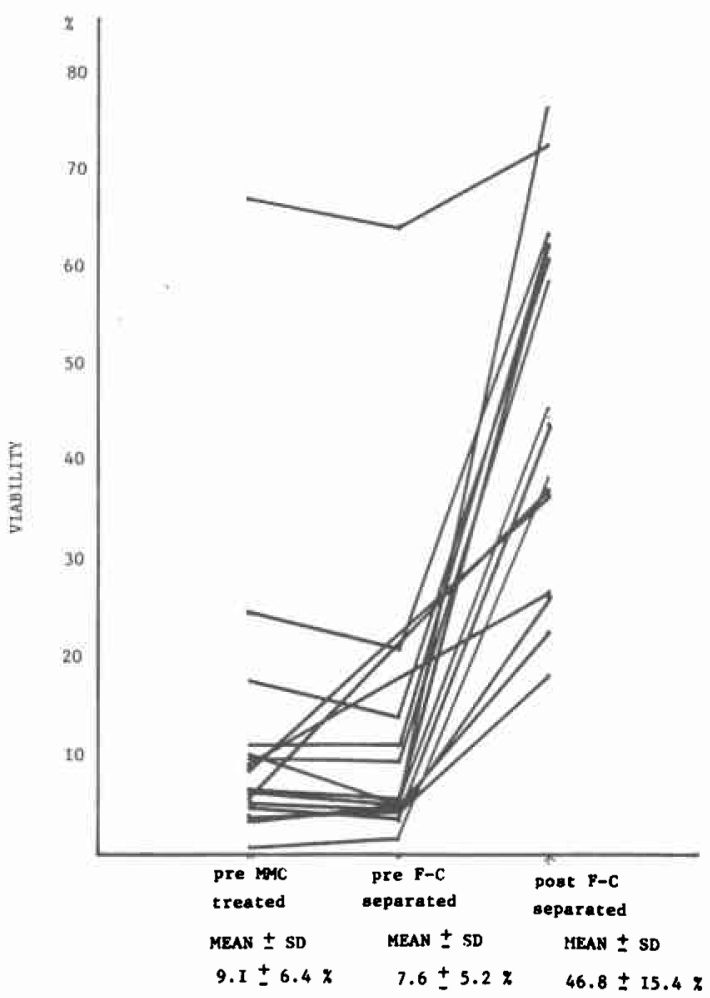

国 3 Optimal response of peripheral lymphacytes to autochonus tumor cells
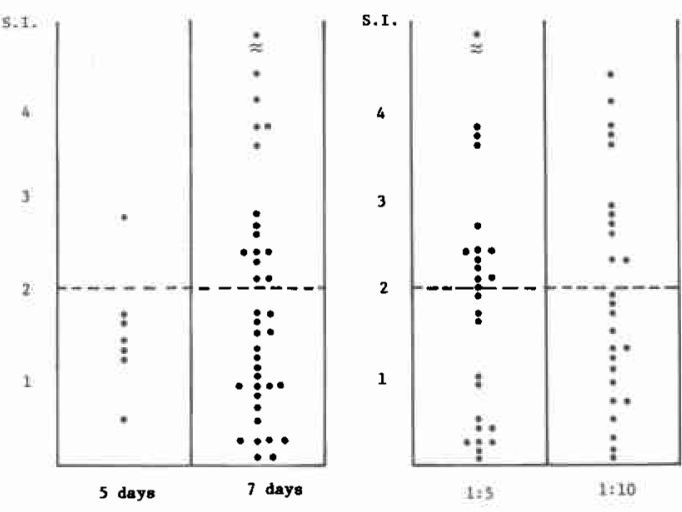

( culcured for 7 days)

2）MLTR における至適培養条件

培養日数および腫缸細胞とりンパ球の比率を検討し た. 培養日数についてみると，5 日間培養では 7 例中 1 例 $(14.3 \%)$ に陽性例がみられたが，7 日間培養では37 例中15例 $(40.5 \%)$ に陽性例がみられ，7 日培着に陽性
例が高く認められたので以後 7 日間培養を施行した. 尰 算細胞とリンパ球の比率は，26例中 $1 ： 5$ で13例（50 $\%$ ，1：10で11例 (42.3\%) と1：5の比率に陽性例 がやや高く認められた（図 3). 個々の症例についてそ の比率の推移をみると, 症例により一定の傾向は認めな かった（図 4 ）. 以後両此率について施行し，反応性の 最大值を採用した。

图 4 Optimal responses of peripheral lymphocytes to autochtonus tumor cells

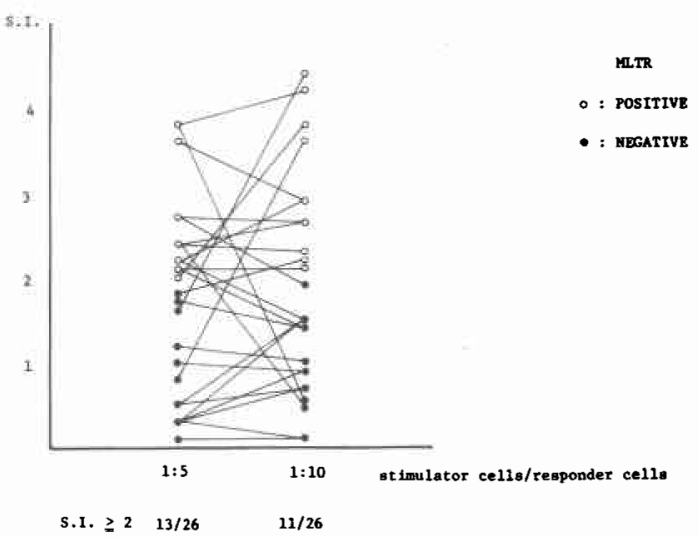

図 5 Comparison of mixed lymphocyte tumor culture reaction in malignant disease

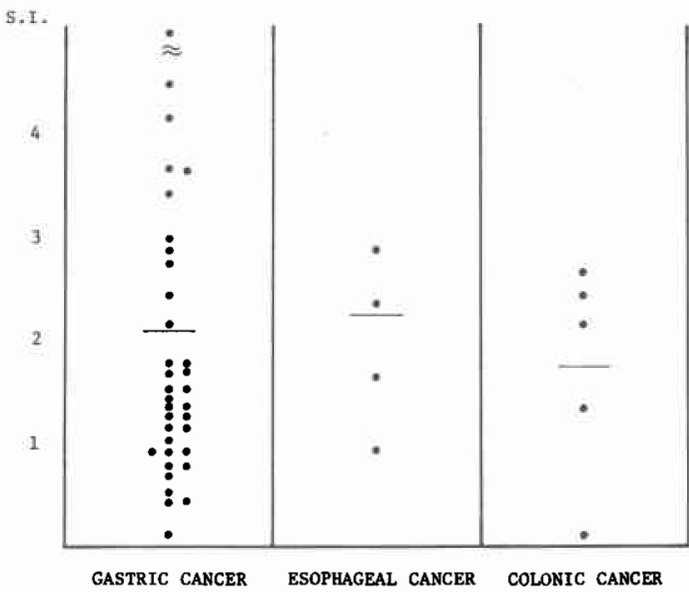

3）各疾患別の MLTR の陽性率

stimulation index (S.I.) 2.0以上を陽性とした. 食道 癌では 4 例中 2 例 $(50 \%)$, 胃癌 では35例中11例 (31.4 $\%)$ ，大腸癌では 5 例中 3 例 $(60 \%)$ で全体 で44例中16 例 (36.4\%) が陽性であった（図 5 ). 
図 6 Mixed lymphocyte tumor cell culture reaction in each stage of gastric cancer

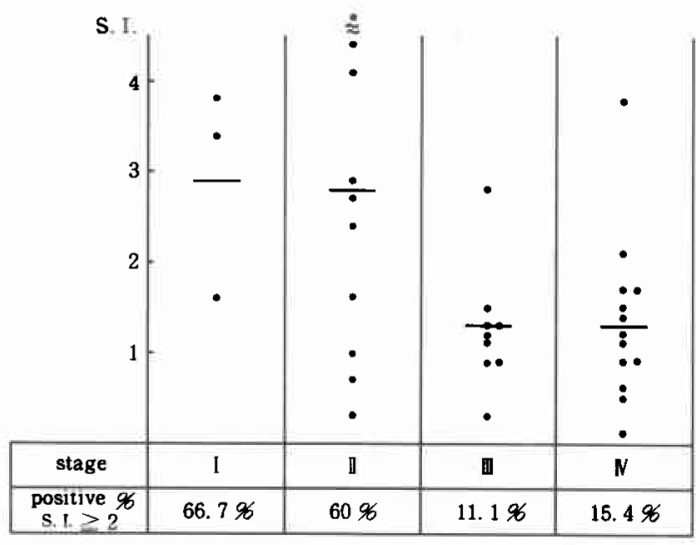

4）胃癌に和ける MLTR

胃癌患者35例につき進行度と陽性率の関係をみると， stage I は 3 例中 2 例 $(66.7 \%)$, stage II では10例中 6 例 $(60 \%)$, stage III では 9 例中 1 例 $(11.1 \%)$, stage IV では13例中 2 例 $(15.4 \%)$ が陽性であり，癌が進行する に従って陽性率は低下する傾向を示した（図6）.

以上よりヒト癌に括いても隀瘍特異抗原の存在が示唆 されまた癌が進行するにつれ感作リンパ球の抗原認識 力の低下が認められた。

(2) 局所的免疫応答

対象は胃癌患者で手術時領域りンパ節として第 1 群り ンパ節の採取できた18例である.リンパ節は一症例あた り $2 \sim 4$ 個採取し, リンパ節リンパ球の反応性は, 採取 したりンパ節の反応性の総和を, 採取リンパ節数で除し た平均値を用いた。

i ) PHA 幼若化率

末梢血リンパ球, 領域リンパ節リンパ球, 腸間膜根部 より採取した遠隔リンパ節リンパ球の PHA 幼若化率

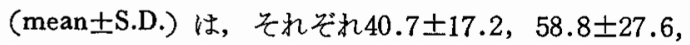
$39.6 \pm 24.4$ であり, 末梢, 遠隔リンパ節リンパ球に比 し，領域リンパ節リンパ球の反応性の上昇が垫められた (図 7). 進行度と領域リンパ節の PHA 幼若化率の関係 をみると, stage I では21.3土10.8, stage II では108.7

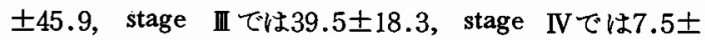
1.6であり, stage II 症例では, stage I, III, IV症例に 比し領域リンパ節リンパ球の PHA 幼若化率の上昇を認 めた（図8).

ii) 特異的免疫能

MLTR を指標にして 検討すると，末梢血りンパ球，
図 7 Response of PHA induced blastoid transformation between peripheral, regional \& distant lymph node lymphocyte in gastric cancer

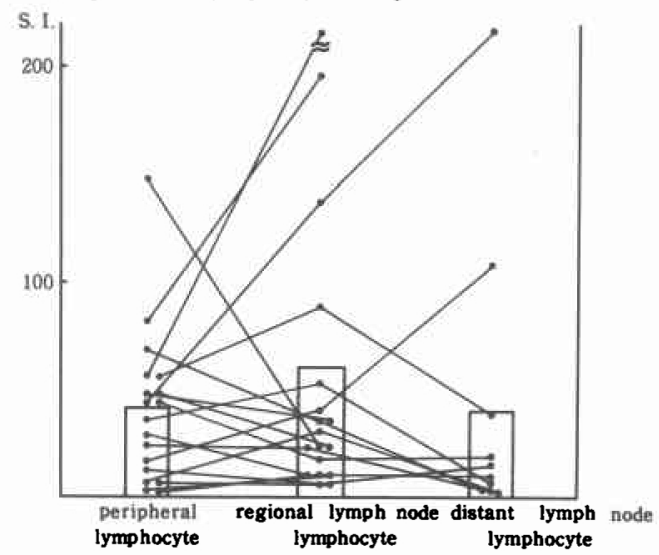

図 8 Response of PHA induced blastoid transformation between peripheral, regional and distant lymph node Iymphocyte in each stage of gastric cancer

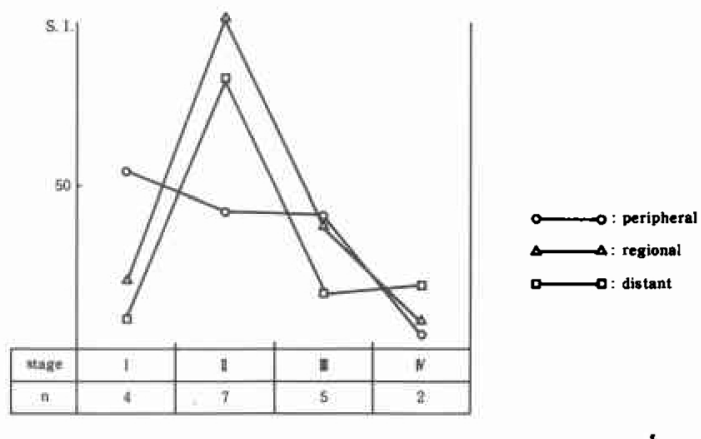

領域リンパ節リンパ球, 遠隔リンパ節リンパ球の MLTR (mean士S.D.) は乞れぞれ $2.4 \pm 1.1 ， 2.7 \pm 1.5 ， 2.3 \pm$ 1.3であり, PHA 幼若化率と同様領域リンパ節リンパ球 に反応性の上昇を認めた。 また S.I. 2.0以上の陽性例を みると，末梢血 リンパ球では17例中 7 例 (41.1\%)，領 域りンパ節リンパ 球では17例中 8 例 $(47.1 \%)$, 遠隔り ンパ節リンパ球では 8 例中 3 例 $(37.5 \%)$ であり, 領域 リンパ節リンパ球にやや多く陽性例を認めた. 末梢血り ンパ球との反応性を比較すると，17例中 9 例 (52.9\%) に領域リンパ節リンパ球での反応性がより高くなる㑯向 を認めた（図9).

進行度と領域リンパ節リンパ球の反応性をみると,

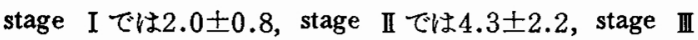

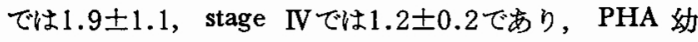


図 9 Response of MLTR between peripheral, regional and distant lymphnode lymphocyte in gastric cancer

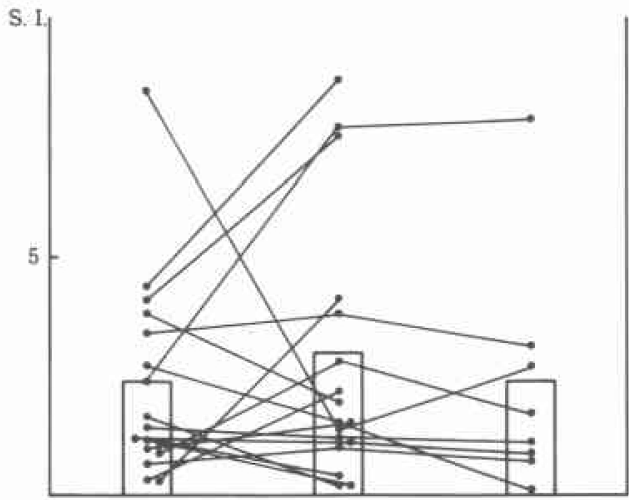

peripheral

regional

distant

S.1. $\geq 2 \quad 7 / 17$

$8 / 17$

$3 / 8$

(41.1\%)

(47. 1\%)

(37.5\%)

图10 Response of MLTR between peripheral, regional and distant lymph node lymphocyte in each stage of gastric cancer

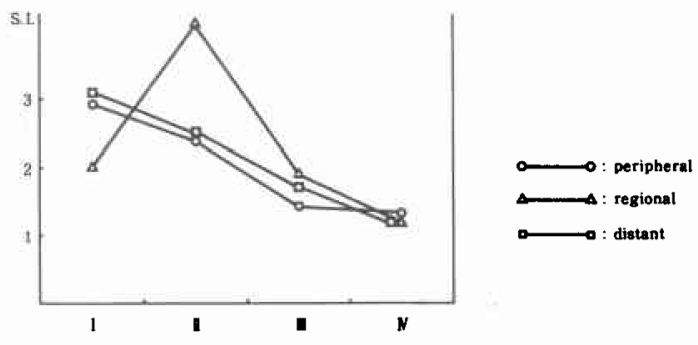

若化率と同様 stage II 症例に領域リンパ節リンパ球で反 応性の上昇を認めた（図10）。

（3）非特異的免疫療法の特異免疫能に及洔す影響 進行癌患者では免疫能の低下が著明であり, 術前より 非特異的免疫療法を施行している. 非特異的免疫療法に より特異免疫能の改善が期待できるかどらかを倲結保存 したリンパ球を用いた MLTR を指標にして検討した。

i ) 凍結保存りンパ球の機能保持

手術前 1 週間に末梢血リンパ球を採取し，前記方法で 保存した. 保存したリンパ球の機能保持は PHA 幼若化 率を指標にした。保存前後での PHA 幼若化率は図11 のごとく, 凍結してもリンパ球の機能は保持されてい る.

ii) 特異免疫能 (MLTR) の変動

胃癌 4 例, 直腸癌 1 例の計 5 例で MLTRを施行し
図11 Corelations between pre and poststored $\mathrm{T}$-lymphocytes on functions in cancer patients

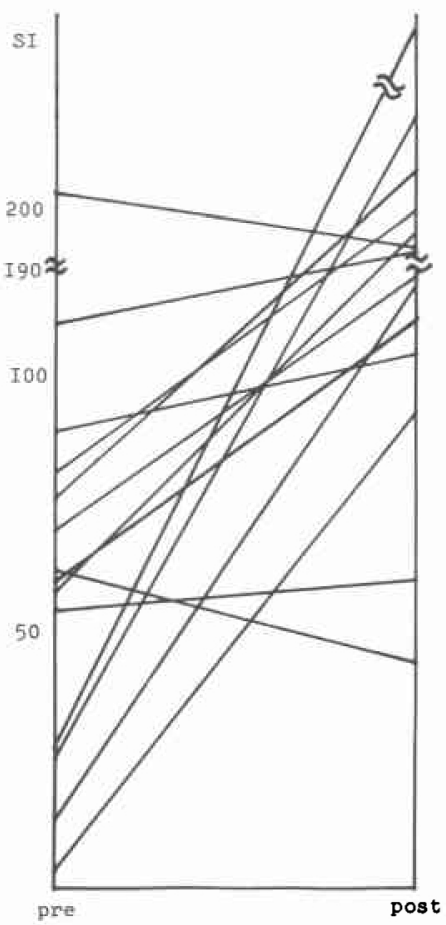

た. 非特異的免疫能は全例改善を認めたが，非特異的な むのと特異的免疫能が平行して変動したものが 5 例中 3 例 $(60 \%)$ であった (図12).

（4）術前の免疫療法による領域リンパ節の免疫応答 進行胃癌12例を対象として, 術前に免疫賦活剤を投与 された群 8 例 (BCG 4 例, Levamisole 2 例, Bestatin 2 例）と非投与群 4 例に分け, 領域りンパ節の免疫能 を比較検討すると，PHA 幼若化率 (S.I.=mean土S.D) では，非投与群17.7土11.4であるのに対して，投与群で は36.4土17.5であった. MLTR では, 非投与群1.5土 0.3 , 投与群 $2.1 \pm 1.6$ であり免疫賦活剂投与群 では非投 与群に比し, 非特異的および特異的にも領域リンパ節の 反応性の上昇を認めた（図13）.

（5）外科的手術の免疫能に及ぼす影響

対象は胃癌で根治手術の施行し得た40例である.末梢 血リンパ球は術後 1 週目より 1 力月まで毎週採取した. 術後 1 週目では, stage I〜IIの比較的早期の症例では 術前値の30～50\%まで低下を認めるが， stage III IVの 進行癌では術前值の 20 2 $5 \%$ となり低下傾向は一層著明 である，術後 4 週目では, stage I ではほぼ術前值にま 
図12 Changes of specific (MLTR) and nonspecific (PHA induced blastogenesis) parameters before $\&$ after immunotherapy

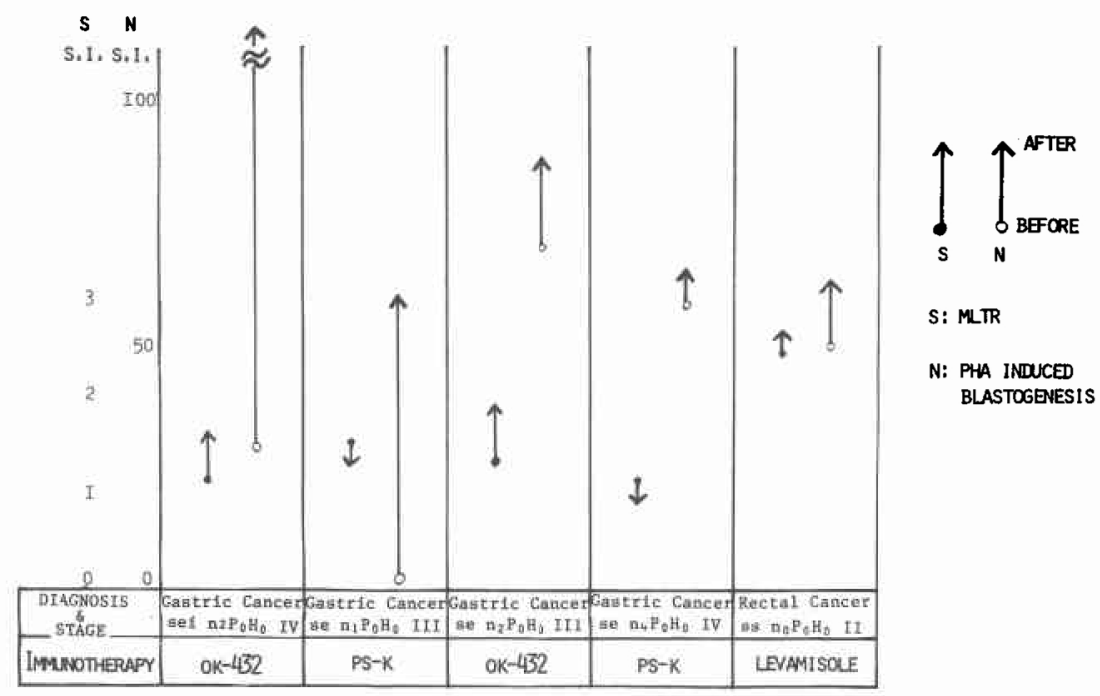

図13 Immjnological responses of preoperative immunotherapy

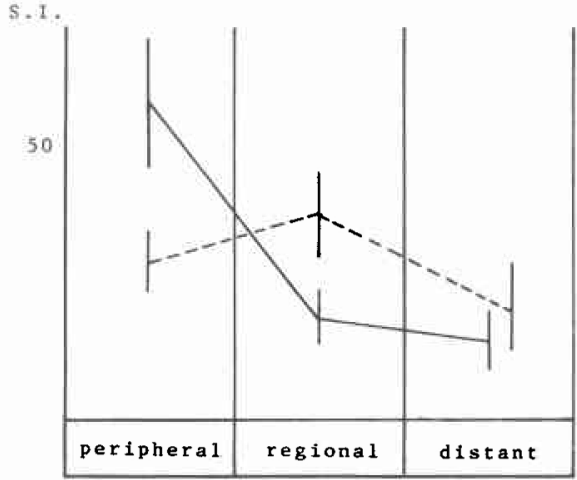

PHA BLASTO.

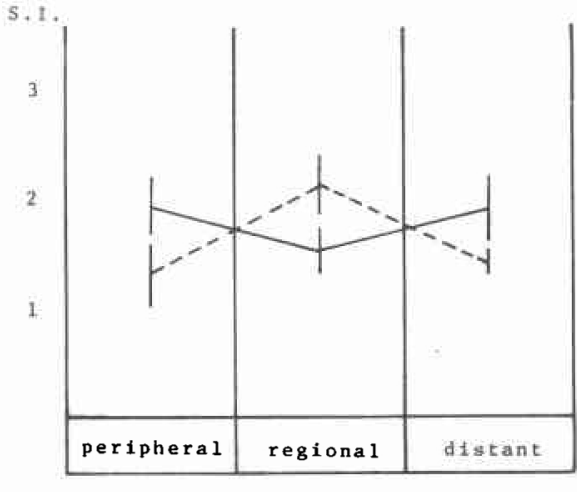

MLTR
で免疫能の回復を認めるが, stage II で70\%, stage III で 50\%, stage IVで30\%であり, stage が進行するにした がって免疫能の回復傾向の遅延を認めた（図14）.

\section{IV 考 察}

担癌生体の細胞性免疫能は, in vitro において種々の 方法で検索されている．著者はリンパ球幼若化反応を指
標として検討した. 担癌生体の免疫能の低下の原因とし て, 癌患者の血清中に増加する腫湟関連抗原 (T.A.A), blocking factor などの体液性因子と, suppressor $\mathrm{T}$ cell を中心とした細胞性因子が考兄られている. Mannick ら ${ }^{18}$ は, 癌患者より採取したリンパ球を 6 回洗滌するこ とにより，PHA に対する反応性が上昇することから， 
図14 Changes of PHA blastogenesis after surgery in each stage of gastric cancer

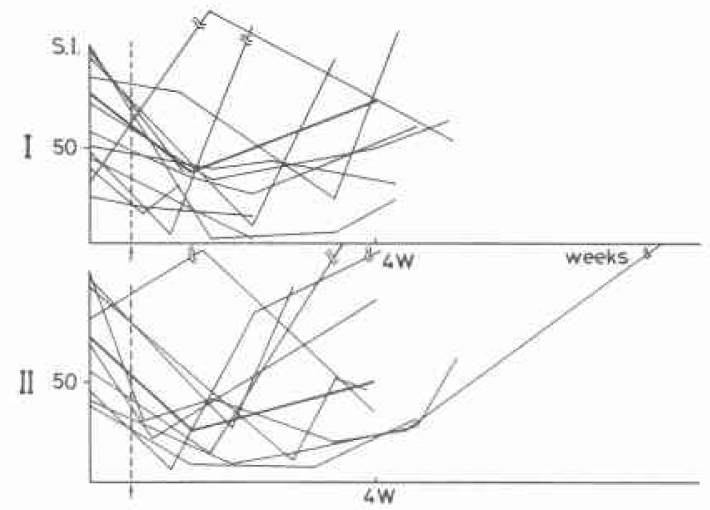

III

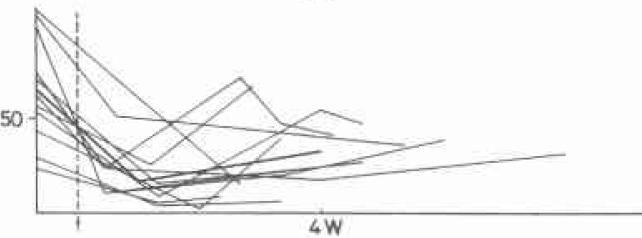

IV 50

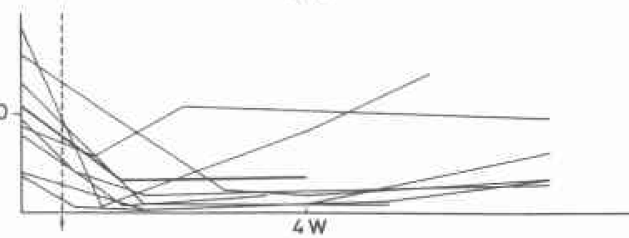

blocking factor はリンパ球膜面に可逆的に付着し, 抗原 に対するリンパ球の反応性を低下させていると報告して いる. また Rangel ら ${ }^{19}$ 怆, melanoma の患者の血清を 正常のリンパ球に添加することにより， mitogen に対す る反応性が低下し，乙かも進行度の進んだ患者の血清程 強く抑制することから，体液性抑制因子は腫瘍由来ない しは腫瘍自体が産生しているのではないかと述べてい る. 一方細胞性抑制因子は，種々の系の動物実験で担癌

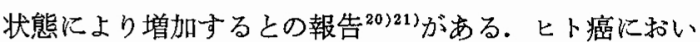

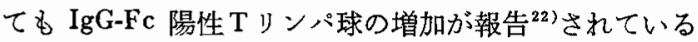
が，一定の見解はない，著者は PHA 幼若化率を指標に 検討したが，癌患者では健康人に比し幼若化率の低下を 認め $(\mathrm{p}<0.01)$ ，また癌の進行に伴っても低下し，正常 リン地球に癌患者血清を添加すると反応性の低下を認め た.このことより担癌状態での非特異的免疫能の低下に は，体液性因子の関与が示唆された，非特異的免疫能測 定に用いられる mitogen は PHA の泳か Concanavalin A (Con A), Pokeweed mitogen (PWM) がある.ヒト
リンパ球に Con A を添加することにより非特異的な suppressor T cell が誘導されるが23)24)，この suppressor cell の役割は細胞性免疫を解析する上で重要であると思 われる.

担癌生体の腫瘍特異免疫能を in vitro で測定する方 法として, 腫瘍細胞障害試験, コロニ一阻止試験, マク ロファージ遊走阻止試験，自己腫復抗原を用いた幼若 化反応などがある．著者はりンパ球自家腫瘍混合培盖 （MLTR）を指標にして検討した，MLTR では生さた腫 瘍細胞を使用する必要があるが，七ト癌では高い生腫瘍 細胞を得ることの困難さや，培養条件，混合培養する腫 疸細胞の前処置など検討されるべき問題がある.

高率の生隀瘍細胞を得る方法として, Ficoll-Conray 法 ${ }^{25)}$ により死細胞の除去がなされており，著者はVanky ら ${ }^{26)}$ の方法により死細胞を除去し反応性の向上を認め た。

採取した腫瘍細胞の不活性化に関して, MMC 処理が 優れているとの報告 ${ }^{27)}$ や, ${ }^{60} \mathrm{Co}$ 照射が安定しているとの 報告 ${ }^{28)}$ があるが，腫場系で検討する必要がある．著者の 実験系では, MMC 処理のみで検討したが腫湢細胞への ${ }^{3} \mathrm{H}-\mathrm{T} \mathrm{dR}$ の取り込みも安定しており，簡便で有効な方法 と考えられた. MLTR の至適培養日数，およびリンパ 球と腫瘍細胞の比率に関しては報告者によって異ってい る ${ }^{2930) 311}$. 著者の成績では7 日培養に陽性例を多く認め た. 腫瘍細胞とリンパ球の比率では症例により一定の傾 向は認めなかったが，1：5で13例，1：10で11例の陽 性例を認めた. MLTR による消化器癌の陽性率は, 胃

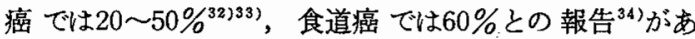
る. 著者の成績では，食道癌で50\%，胃癌で $31 \%$ 陽珄 率を認めた。 なた胃癌症例では比較的早期の癌に高い陽 性率を認め, 山岡 ${ }^{32)}$ の報告と同様に進行度と逆相関を示 した，胃癌に和ける MLTR の陽性率が低いことは，抗 原性の弱いこと，抑制因子の関与が考学られるが今後検 討されるべき問題である.

担癌生体の腫瘍免疫を考察する際, 全身的なるのと 腫瘍に近い局所の免疫能を区別して考学る必要がある. とくに癌病巣に所属するリンパ節細胞には，腫瘍細胞の 増殖を抑制する biological な barrier が存在すると考え られている ${ }^{35)}$. 著者は胃癌患者を対象として, 領域リン 次節の免疫能を PHA 幼若化率，MLTR を指標にして 検討した。

領域りンパ節の抗腫瘍性について, Ambus ら ${ }^{36)}$ は34 
人の種々の癌患者を対象に検討しているが，PHA 反応 は末梢血リンパ球伅反応性の高い傾向があるが，MLTR の陽性率では末末梢血リンパ球が $41 \%$ であり 領域りン パ節リンバ球では $47 \%$ に陽性例を認め,さらに進行度 にみると, stage I 〜 II 症例では末梢血リンパ球に反応 性が高く, stage III〜IVの進行癌になると領域リンパ節 リンパ球に反応性の上昇をみたと報告している。ささらに Deodhar ら ${ }^{37}$ は17人の乳癌患者を対象に PHA 反応, MLTR を施行し, PHA 反応では両者間に差を認めな かったが MLTR では領域りンパ節リンパ球に反応性 の上昇を認めたと述べている.一方領域りンパ節の抗腫 瘍性に関して反対の意見もある. Nairn $5^{38) 39}$ は悪性 黒色腫, 大腸癌患者を対象に腫瘍細胞障害試験で倹討し ているが，領域リンパ節リンパ球には殺紐胞性は認めな かったと報告している．著者は胃癌患者を対象に検討し たが，PHA 幼若化率，MLTR はともに領域リンパ節 リンパ球に反応性の增強を認めた。 また進行度別にみる と, stage I 症例では領域りンパ節リンパ球に反応性の 上昇は認めなかったが， stage II 症例では著明に反応性 の増強を認めた. stage $\mathbb{I I} 〜 \mathrm{~N}$ の進行癌ではともに低下 を認めた。

このことから領域りンパ節には腫瘍巣の㧪がりを防御 寸る biological barrier が存在し, 腫瘍細胞の転移を防 止する機能が存在するるのと思われる.

進行癌患者では著明に免疫能の低下が認められている ため, 手術前より非特異的免疫療法が施行されている。 非特異的兔疫療法の効果判定を, MLTR を指漂にして 検討した報告は見当らない, 著者は術前の免疫療法開始 前に末梢血リンパ球を採取凍結保存し，手術当日採取 した腫崲細胞との間で混合培養し, 特異免疫能の変動を 検討した. 凍結保存したリンパ球の機能保持に関して Wood $5^{(0)}$ は 8 人の腎移植供給者のリンパ球を用いて 検討し, PHA 反応は保持されると述べている. Strong $ら^{41}$ は $\mathrm{C} 3 \mathrm{H} / \mathrm{HeJ}$ マウスの spleen 中の T-cell は凍結操 作により損傷を受けるが，B-cell は汪とんど機能が保 持されており，この相違は細胞膜の性質によるるのでは ないかと報告している，著者は癌患者のリンパ球を凍結 保存し, PHA 幼若化能で検討したが, 凍結保存したり ンパ球の機能は保持されることが判明した.

免疫療法の免疫能汇及活す影響に関して Lipson ら ${ }^{42}$ は55例の肺癌患者に thymosin 療法を施行し, 投与群 では非投与群に比し末梢血中の T-cell の增加が認めら れ, また T-cell 增加群では予後の良好な症例が多く認
められたと報告している. Cheema and Hersh'43) は, in vitro で PHA で刺激した自己のリンパ球を腫瘍内に 局注することにより, 腫瘍の完全消失ない乙部分的縮少 が認められ，PHAで刺激したりンパ球にも抗腫瘍性が 認められると述べている. 著者は非特異的免疫療法によ る特異免疫能の変動を, MLTR を指標にして検討した が， 5 例中 3 例飞特異免疫能の改善を認めた．をた進 行胃癌患者 4 例につき, 術前 $2 \sim 1$ 週に BCG cell wall vaccine $3 \mathrm{mg}$ を腫瘍内に投与し, 領域リン八節の免疫 能を検討したが，末梢血りンパ球に比し領域リンパ節リ ンパ球では, PHA 幼若化率, MLTR はともに著明に 反応性の上昇を認め, 非特異的免疫療法によっても, 西 る程度特異免疫能の改善が期待でき，また兔疫賦活剈の 腫瘍内投与により領域りンパ節の特異免疫能の上昇を認 め, 微小残存する癌細胞に対して効果があるるのと思 われる。

担癌生体の細胞性免疫能の低下は, 癌の進行にともな ら体液性および 細胞性抑制因子の増加に起因している が，外科領域の癌に対しては外科手術により腫韵細胞の 除去が可能であり, 体液性和よび細胞性抑制因子の減少 をはかることが可能である. 事実腫瘍摘出後これら抑制 因子の減少がみられたとの報告 ${ }^{44}$ がある. 一方外科手術 の影響による T細胞の mitogen に対する反応性につい て, 癌患者以外や外傷患者でも術後早期には低下する が，数日後には急速に回復するとの報告がある ${ }^{45) 467}$. ま

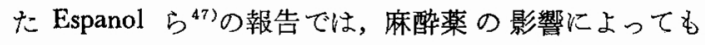
PHA 反応の低下が認められると述べている. 癌患者で は術前より immunosupresive の状態が認められている。 Watkins ${ }^{48)}$ は36人の癌患者を治癒切除例に別け検討して いるが, 術後 6 週目の PHA 反応では, 非治癒切除例 では術前値にまで回復する症例が少ないが，治瘾切除例 では術前値以上に回復する症例が多く認められ，これは 治宿切除により血清中の抑制因子の消失が原因であるう と報告している. 著者は胃癌患者を対象に検討したが, stage I 〜 II 症例では術後早期より回復する症例が多く 認められ, stage I 症例では術後 1 力月で注術前值に まで回復しているが, stage $\mathbb{I I} \sim \mathrm{N}$ 症例では術後の回復 傾向の遅延が認められ, 特に stage IV症例では術後数カ 月経過しても低值にとどまっている症例が多く認められ た. 進行癌でも腫瘍摘出によりある程度抑制因子の減少 は可能であるが，肉眼的治澺切除であっても他臓器へ の micrometastasis が考兄られ, 術後の免疫能の回復傾 向の遅延があるものと考兄られ今後手術時検討されるべ 
き問題と思われる，事実 Watkins の報告でも治瘾切除， 非治瘾切除沈かわらず術後著明にりンパ球反応の低下 乙た症例では術後 3 カ月までに死亡しておう，術後のリ ンバ球反応の推移が手術の根治性, 予後を判断する指標 となり得ると思われる.

\section{$\mathbf{v}$ 結 语}

消化器癌患者 237 例の 細胞性免疫能をリンパ球幼若化 反応を指標にして検討した。

（1）末梢血リンパ球を用いた全身的な免疫能は， PHA 幼若化反応で码がり健康人に比し癌患者では 有意の低下を認め, 血清中の抑制因子の関与が示唆され た。

（2）胃癌患者を対象にリンパ球自家腫瘍混合培養反 応による特異免疫能は, stage I 〜 II 此較的早期の症 例に多く陽性例を認め, 癌が進行するにしたがって陽性 率は低下する傾向を示した.

（3）胃癌患者で領域りンパ節の採取できた18例を対 象に局所の免疫能を検討すると, stage I 症例では領域 リンパ節の免疫能の上昇は認めなかったが, stage II 症 例では非特異的および特異的にも著明に反応性の上昇を 認めた. stage $\mathbb{I I} 〜 \mathrm{~N}$ の進行癌ではともに低下を認めた が， stage $\mathrm{I}$ 症例では遠隔りンパ節にやや反応性の上昇 を認めた。

（4）凍結保存りンパ球を用いて非特異的免疫療法に より MLTR を指標とした特異免疫能の变動を検討する と, 5 例中 3 例に特異免疫能の上昇を認め, 非特異的免 疫療法によってもある程度特異免疫能の改善が期待でき る.

（5）胃癌患者を対象飞術前 BCG 腫崵内投与に上る 非特異的免疫療法を施行すると, 非特異的扔よび特異的 にも領域リンパ節の反応性の上昇を認め, 手術時残存す る微小癌に対して効果があるるのと思われる.

（6）胃癌患者で治窟切除のできた症例につき，外 科手術の免疫能に及ぼす影響につき検討した。術後の adjuvant therapy の開始される術後 2 週目では, stage $\mathrm{I} \sim \mathrm{N}$ ではすべて術前值の 20 \% $60 \%$ であり, 特に stage $\mathrm{IV}$ 症例では術後 1 カ月を経過しても術前值まで回復しな い症例が認められた。

本論文の要旨は第 $15 ， 16 ， 17$ 回日本癌治療学会総会, 第14回日本消化器外科学会, 第80回日本外科学会総会飞 拈いて発表した。

稿を終るに臨み，ご指導とご校閱を賜った京都府立医 科大学第 2 外科教室橋本勇教授に深甚なる謝意を捧げる
とともに，終始直接にご指導，ご助言下さった滋賀医科 大学第 1 外科学教室小玉正智教授に深く感謝の意を表す る.

\section{文献}

1) Shortman, K. et al.: Characterisation and separation of mouse lymphocyte subpopulation responding to phytohemagglutinin and pokweed mitogem. Cancer Immunol, 6 : 25-40, 1973.

2) Glaser, M. et al.: Study of the cellular immune response to Gross virus-induced lymphoma by the Mixed Lumphocyte-Tumor Interaction. Cancer Res. 34 : 2165-2171, 1974.

3) Deckers, P. et al. The effect of tumor size on concomitant tumor immunity. Cancer Res. 33: 33-39, 1973.

4) Nowell, P.C.: Phytohaemagglutinin. An initiation of mitosis in cultures of normal human leukocytes. Cancer Res. 20 : 462-466, 1960.

5) Greaves, M.F. et al.: Activation of human $T$ and $B$ lymphocytes by polyclonal mitogens. 248: 698-701, 1974.

6) Martyn, W.B. et al.: Refractoriness of lymphnode cells from tumor-bearing animals. Int. J. Cancer $15: 99-108,1975$.

7) Boyer, P.J.J. et al.: Stimulation of lymphoid cells from normal and immune mice by syngeneic BALB/c plasma cell tumors. J. Immunol. 116 : 202-209, 1976.

8) Gillis, S. et al.: In vitro generation of umorspecific cytotoxic lymphocytes. Secondary allogeneic mixed tumor lymphocyte culture of normal murine spleen cells. J. Exp. Med. 146: 468-482, 1977.

9) Kanner, S.P. et al.: Experience with a mixed lymphocyte tumor reaction as a method of detecting antigenic differences between normal and neoplastic cells. J. Immunol. $105: 1052-$ 1055, 1970.

10) Stjernsward, J. et al. Indications of cellular immunological reactions against autochthonous tumor in cancer patients studied in vitro. $E$. Afr. Med. J. 45 : 485-497, 1968.

11) Foca, N.S. et al.: Impaired responsiveness of lymphocytes and serum inhibitory factors in patients with cancer. Cancer. Res. $33: 2373-$ 2377, 1973.

12) Tanaka, F. et al.: Blocking factors in sera of breast cancer patients. Cancer $43: 838-847$, 1979.

13) Takei, et al.: Charization of suppressor cells in mice bearing syngeneic mastocytoma. J. Immunol. 118:412-417, 1977. 
14) Crowley, J.P. et al.: The recovery, structure, and function of human blood leukocytes after freeze preaservation. $11: 395-409,1974$.

15) Golub, S.H. et al.: The use of viable frozed lymphocytes for studies in human tumor immunology. Transplantation $19: 195-202,1975$.

16) Mangi, R.J. et al.: The in vitro transformation of frozen-stored lymphocytes in the mixed lymphocyte reaction and in culture with phytohemagglutinin and specific antigens. J. Exp. Med., $132: 401-416,1970$.

17) 胃癌研究会: 外科, 病理, 胃癌取扱い規約改訂 第10版. 金原出版, 東京, 1979.

18) Mannick, J.A.: Improvement of phytohemagglutinin responsivenes $s$ of lymphocytes from cancer patients after washing in vitro. Cancer Res. 37 : 3066-3070, 1977.

19) Rangel, D.M. et al.: Demonstration of lymphocyte blastogenesis-inhibiting factors in sera of melanoma potients. Surgery. $82: 224-232$, 1977.

20) Argyris, B.F.: Suppressor cells in the spleen of tumor-allosensitized mice. Cancer Res. 37: $3390-3399,1977$.

21) Eisenthal, A. et al: Induction of allospecific suppressor $\mathrm{T}$ cells in vitro Cellular Immunol. $34: 112-124,1977$.

22）新保敏和注か：ヒト IgG-Fc receptor 陽性 T リンパ球の検出法と各種疾患における変動。臨 床免疫, 9：141-145, 1977.

23) Hubert, C. et al.: Concanavalin A-activated suppressor cells in normal human peripheral blood lymphocytes. Clin. Exp. Immunol. 26: 95-98, 1976.

24) Sakane T., et al.: Human suppressor $T$ cells induced by Concanavalin A. Suppressor $T$ cells belong to distinctive $\mathrm{T}$ cell subclasses. J. Immunol. 119 : 1169-1178, 1977.

25) Mavligit, G.M., et al.: Cell-mediated immunity to human solid tumors: In vitro detection by lymphocyte blastogenic responses to cell-associated and solubilized tumor antigens. Natl. Cancer. Inst. Morgr 37 : 167-176, 1973.

26) Vánky, F., et al.: Lymphocyte stimulation test for detection of tumor-specific reactivity in humans (edited by Barry R. Bloom and John R. David), Academic Press. New York, 597606, 1976.

27) Vánky. F., et al.: Cellular immunity to human sarcoma. J. Natl. Cancer Inst $\cdot 46: 1145-1151$, 1971.

28) Anderson, R.J., et al.: Lymphocyte blastogenic responses to cultured allogeneic tumor cells in vitro. Cancer. Res. 32 : 988-992, 1972.
29) Vánky, F., et al.: Tumor-associated specificity of serum-mediated inhibition of lymphocyte stimulation by autochthonous human tumors. J. Natl. Cancer Inst. $51: 25-32,1973$.

30) Mavligit, G.M., et al.: Lymphocyte blastogenic responses to autochthonous viable and nonviable human tumor cells. J. Natl. Cancer Inst. 51 : 337-343, 1973.

31) Dean, J.H., et al.: Cell-mediated immune responses of breast cancer patients to autologous tumor-associated antigens. J. Natl. Cancer Inst. $58: 549-555,1977$.

32) 山岡 博：癌患者に打仃る癌特異的細胞性免疫 能に関する研究。札幌医誌，46：341-353, 1977.

33) Ieda, H., et al.: Mixed lymphocyte-tumor cell culture reaction in cancer patients. GANN 69: $417-421,1978$.

34) 西平哲郎：各種人癌に打けるリンパ球一腫瘍混 合培蕞反応，癌の臨床, $24: 961 一 968,1978$.

35) Kurokawa, Y.: Experiments on lymph-node metastasis by intralymphatic inoculation of rat ascites tumor cells, with special reference to lodement, passage, and growth of tumor cells in lymph-node. GANN 61 : 461-471, 1970.

36) Ambus, U., et al.: Specific and non-specific immunologic reactivity of regional lymph-node lymphcytes in human malignancy. Int. J. Cancer $14: 291-300,1974$.

37) Deodhar, S.D., et al.: Study of the tumor celllymphocyte interaction in patients with breast cancer. Cancer 29:1321-1325, 1972.

38) Nairn, R.C., et al.: Anti-tumor immunoreactivity in patients with malignant melanoma. Med. J. Aust. 1 : 397-403, 1972.

39) Nairn, R.C., et al.: Immunological reactivity in patiets with carcinoma of colon. Brit. Med. J. 4 : 706-709, 1971.

40) Wood, N., et al.: A simple method of freezing and storing live lymphocytes. Tissue Antigens 2 : 27-31, 1972.

41) Strong, D.M., et al.: Differential susceptibility of murine $\mathrm{T}$ and $\mathrm{B}$ lymphocytes to freez-thaw and hypotonic shock. Cryobiology 11:127138, 1974.

42) Lipson, S.D., et al.: Thymosin immunotherapy in patients with small cell carcinoma of the lung. Correlation of in vitro studies with clinical course. Cancer 43:863-870, 1979

43) Cheema, A.R. and Hersh, E.M.: Local tumor immunotherapy with in vitro activated autochthonous lymphocytes. Cancer $29: 982-986$, 1972 .

44) 成木行彦ほか: 消化器癌患者の血中 CEA と T 
細胞の関連について. 日本癌治療学会誌, 13 : 107-117, 1978.

45) Slade, M.S., et al.: Immunodepression after major surgery in normal patients. Surgery 78 : 363-372, 1975.

46) Bauer, A.R., et al.: The depression of T lymphocytes after trauma. Amer. J. Surg. 136:674
$-680,1978$.

47) Espanol, T., et al.: The effect of anaesthesia on the lymphocyte response to phytohaemagglut!nin. Clin. exp. Immunol. $18: 73-79,1974$.

48) Watkins, S.M.: The effect of surgery on lymphocyte transformation in patient with cancer. Clin. exp. Immunol. $14: 69-76,1973$. 